\title{
Spring Meeting Plenary Questions Earthquake Prediction Theories
}

Mark D. Zoback, plenary speaker at the 1990 MRS Spring Meeting in San Francisco, will present some intriguing data that suggest that the recent quake in San Francisco was not accurately predicted, and that as a result all the models may be seriously in error.

Substantial evidence supports the applicability of frictional faulting theory and laboratory-derived coefficients of friction to the mechanics of faulting and the resulting state of stress within continents. But, according to Zoback, a professor of geophysics at Stanford University, "an equally convincing body of evidence indicates that major strike-slip faults, like the San Andreas, can slip at extremely low levels of shear stress."

"The implications of these observations," says Zoback, "are that we must re-examine long-held assumptions about the physics of faulting, the nature of the earthquake cycle, and long-term earthquake probability assessment." Also included in this re-

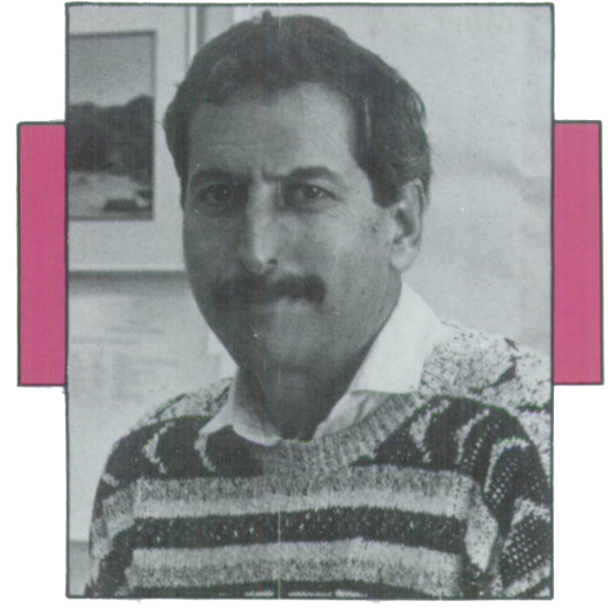

1990 Spring Meeting Plenary Speaker, Mark D. Zoback, professor of geophysics at Stanford University, will shake a few theories about earthquake prediction when he offers "Some New Views of the State of Stress Along the San Andreas Fault." examination would be assumptions about the style of crustal deformation along strike-slip plate margins and assumptions about the fundamental stress boundary conditions that constrain the driving mechanisms of plate tectonics.

Zoback has BS, MS, and PhD degrees in geophysics from the University of Arizona and Stanford University. He served as a visiting scientist at the Rhur University in Bochum and worked with the U.S. Geological Survey as chief of the In-Situ Stress Measurement Project, deputy chief of the Office of Earthquake Studies, and chief of the Branch of Tectonophysics before joining the Stanford faculty in 1984. The author of numerous papers and member of several professional societies, he is also a Fellow of the Geological Society of America and the American Association for the Advancement of Science. Zoback serves on several advisory bodies and editorial boards in his field and has been a member of the National Earthquake Prediction Evaluation Council since 1984.

\section{Short Course Program}

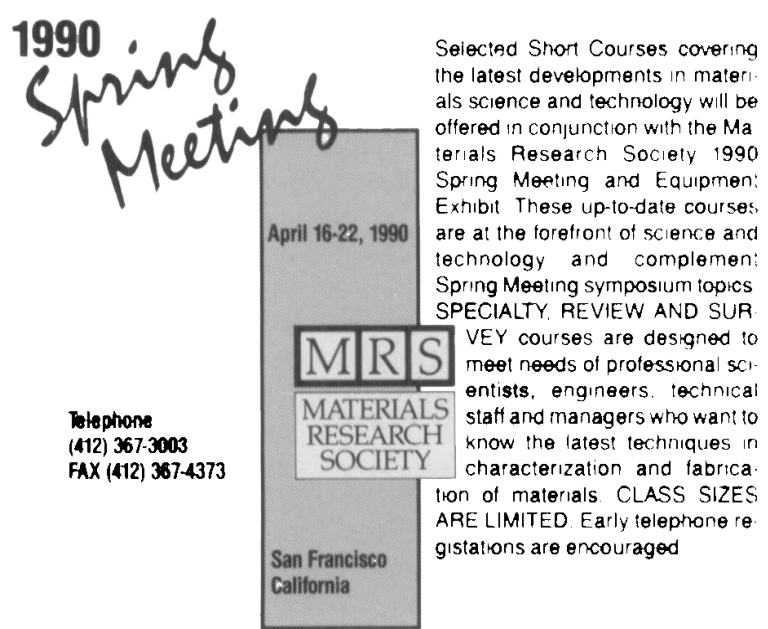

AOVANCED MATERLALS

M-04 Optoelectronite Materlats, Processes, and Devices

Instructor: Mool C. Gupta

Friday-Saturday, Aprll $20.21 \ldots \ldots \ldots \ldots \ldots \ldots \ldots \ldots \ldots \ldots$

M-OS Fabrtitation, Charactertzation, and Applications of High-Temperature

Superconducting Materitats

Instructors: Terry P, Orlando and Robert E. Schwall

Monday-Tuesday, April 16-17

M-0s Growth and Charactertzetion of Diamand and Dlamond Films

Instructors: Daniel L. Flamm, Thomas A. Anthony, and Jettrey T. Glass

Tuestay, April 17.

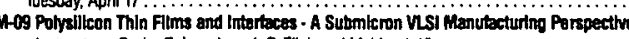

Instructors: Bruha Raicu, Joseph P. Ellut, and Mahboob Khan

Friday-Saturday, April 20-21....

PAEPARATIOH AND FABRICATION OF MATERLALS

P-07 Sol-Ged Processing of Glass

Instructors: $C$. Jeffrey Brinker and George W. Scherer

Saturday-Sunday, April 21-22
P-09 Matertals Processing In Thermal Plasmas

Instructors: Maher I. Boullos, Pierre Fauctais, and Emill Ptender

Thursday-Saturday. April 19.21 .... Instructor: Donald M. Mattox Friday-Saturday, April 20-21

P-15 Ohmic Contacts to Semlconduetare

Instructor: Peter A. Bames

Friday. April 20 . .

P.17 Matertals Processing by Vapor Phase Techniques

Instructor: Toivo Kodas

Thursday. April 19.

P.19 Compound Serniconductor Epltary and Processing

Instructors: Ami Appelbaum and L. Ralph Dawson

Tuestay - Thursday, Aprit 17-19.

Fon Fitm and Costing Deposstion Techntques

Instructor: Donald M. Mattox

Tuesday-Wednesday, April 17-18

Fo2 Plasma Etthing tor Micruelectronit Fabritation

Instructor: G. Kenneth Hert

Thursday, April 19

Cerenic Packaging of Intoprated

Instructor: George C. Prillips

(1)

P Mlcrowave interactions with Dielectrtc Matertals

Instructors: Hal D. Kimrey, Ralph W. Buce, and Magdy \&. Iskander

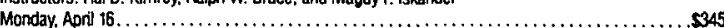

TECHMIQUES

HOT lon Source Fundamentat

Instructor: lan 6. Brown

Wednesday, April 18.

CHARACTERIZATION OF MATERIALS

C-10 Surtace and Thin Film Analysts

Instructors: Leonard C. Feldman and James W. Mayer

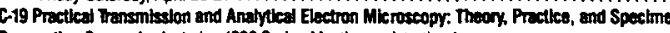

paration Course feg inctudes 1990 Spring Meeting registration fee

Instructors: Alton D. Romig. Jr., David B. Willians, and Ron M. Anderson

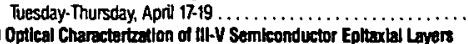

C-20 Optical Charactertation of

Instructor: Gary W. Wicks

Friday, April 20 .

\section{SPECIAL DISCOUNTS:}

for those who register tor MRS Shori Courses F-01 and P-14 the special discounted tuition will be 5995. Facilities registering three or more persons at the same time in one MRS Short Course receive a $20 \%$ discount for the thind and all additional persons.

REGISTRATION INFORMATION: Call (412) 367-3003 and ask for the Short Course Otfice to request information about student schotarships. 